\title{
PARTISIPASI MASYARAKAT LEWAT PENGEMBANGAN BANK SAMPAH SYARIAH DI KOTA METRO SEBAGAI UPAYA IMPLEMENTASI PERDA NO. 08 TAHUN 2015 TENTANG PENGELOLAAN SAMPAH DI KOTA METRO
}

\author{
Ariza Umami \\ Universitas Muhammadiyah Metro \\ arizaumami86@gmail.com
}

\begin{abstract}
Abstrak
$\mathrm{P}$ enelitian tentang partisipasi masyarakat lewat pengembangan Bank Sampah Syari'ah sebagai upaya implementasi Perda No. 08 Tahun 2015 tentang Pengelolaan Sampah di Kota Metro ini bertujuan untuk: (1) Untuk mengetahui regulasi terkait pengaturan pengelolaan sampah di Kota Metro;(2) Untuk menemukenali kendala penanganan persoalan persampahan di Kota Metro; (3) Untuk mengetahui dan menemukan model penanganan sampah berbasis partisipasi masyarakat dalam rangka mendukung implementasi Perda Pengelolaan Sampah di Kota Metro; dan (4) Menemukan model pengembangan Bank Sampah Syari'ah untuk pengelolaan sampah di Kota Metro.Jenis penelitian ini adalah penelitian yang menggunakan pendekatan deskriptif kualitatif, yaitu penelitian yang bermaksud mendeskripsikan fenomena yang terjadi dilokasi penelitian dengan menggunakan analisis sosio-legal. Teknik pengumpulan data meliputi wawancara, observasi dan dokumentasi, sedangkan analisis data menggunakan teknik deskriptif kualitatif. Berdasarkan hipotesis penelitian, sangat memungkinkan upaya implementasi Perda No. 08 Tahun 2018 tentang Pengelolaan Sampah di Kota Metro dengan melibatkan partisapasi masyarakat lewat pengembangan Bank Sampah Syari'ah dengan sistem Muraza'ah, yakni sistem yang mengqiyaskan pada sistem ekonomi Islam tentang praktik pengelola lahan pertanian, antara pemilik lahan dan penggarap lahan. Dalam makna praksisnya muzara'ahdalam Bank Sampah Syari'ah adalah memberi hasil penjualan sampah dan tidak boleh seseorang memberi hasil penjualan sampah pada pengurus Bank sampah kecuali dengan pemberian yang sudah dapat diketahui oleh kedua belah pihak baik penabung maupun pelaksana/pengurus Bank sampah.
\end{abstract}

Kata Kunci: Partisipasi Masyarakat, Bank Sampah Sayariah, Perda Pengelolaan Sampah

\section{Pendahuluan}

Bertambahnya penduduk dan perubahan pola konsumsi masyarakat menimbulkan bertambahnya volume,jenis, dan karakteristik sampah yang semakin beragam. Sampah telah menjadi permasalahan nasional sehingga pengelolaannya perlu dilakukan secara komprehensif dan terpadu dari hulu ke helir,pengelolaan sampah diperlukan kepastian hukum,kejelasan tanggung jawab dan kewenangan pemerintah,pemerintah daerah,serta peranserta masyarakat sehingga pengelolaan sampah dapat berjalan secara profisional,efektif dan efisien.

Kekeliruan dalam pengelolaan sampah akan berdampak pada pencemaran lingkungan. Sondang Siagian ${ }^{1}$ menjelaskan bahwa pelestarian lingkungan hidup berada pada peringkat ke-4 dalam 10 tantangan masa depan, sehingga harus mendapat perhatian serius. Pemerintah melalui UU. Nomor 18 Tahun 2008 tentang Pengelolaan berusaha secara serius untuk mengurai, mengantisipasi dan mengurangi persoalan sampah tersebut. Selama ini masyarakat pada umumnya melakukan pengelolaan sampah melalui proses pengumpulan, pengangkutan dan pembuangan ke tempat pembuangan akhir sampah/TPAS (end of pipe/). Padahal, setiap masyarakat memiliki volume sampah yang besar dan apabila diangkut menjadi satu akan 1 Sondang P. Siagian, Administrasi Pembangunan: Konsep, Dimensi, dan Strateginya. Jakarta, Bumi Aksara, 2003 Hal. 28 
menciptakan timbunan sampah yang besar dan berpotensi melepas gas metan (CH4). Hal tersebut berdampak pada peningkatan emisi gas rumah kaca dan pemanasan global. Maka lewat UU Nomor 18 Tahun 2008 dan PP Nomor 81 Tahun 2012, pengelolaan sampah harus memperhatikan asas tanggungjawab, keberlanjutan, asas manfaat, keadilan, kesadaran, kebersamaan, keamanan dan asas nilai ekonomi, yang pengelolaannya dengan melibatkan peranserta masyarakat.

Sesuai dengan Pasal 3 UU Nomor 18 Tahun 2008 tentang Pengelolaan sampah, disebutkan bahwa :"Pengelolaan sampah diselenggarakan berdasarkan asas tanggung jawab,asas berkelanjutan, asas manfaat, asas keadilan, asas kesadaran, asas kebersamaan, asas keselamatan, asas keamanan, dan asas nilai ekonomi"

Dan diperkuat dengan pasal 35 ayat (1) Peraturan Pemerintah Nomor 81 Tahun 2012 Tentang Pengelolaan Sampah rumah tangga dikatakan bahwa : Masyarakat berperan serta dalam proses pengambilan keputusan, penyelenggaraan, dan pengawasan dalam kegiatan pengelolaan sampah rumah tangga dan sampah sejenis rumah tangga yang diselenggarakan oleh Pemerintah dan/atau Pemerintah Daerah"

Kedua peraturan diatas secara tegas mengatur bahwa pengelolaan sampah harus didasarkan pada kesadaran bagi pemerintah untuk mengelola sampah dengan baik dan juga peranserta maysarakat sebagai bentuk nyata dari penerapan kebijakan Pemerintah mengenai pengelolaan sampah yang baik dan benar sehingga dibutuhkan peran aktif masyarakat agar meningkatkan kesehatan bagi masyarakat dan kualitas lingkungan serta menjadikan sampah sebagai sumber daya.

Kota Metro sebagai kota kedua setelah Kota Bandarlampung di Provinsi Lampung, dengan luas wilayah $68,74 \mathrm{~km} 2$ atau 6.874 ha, dan jumlah penduduk 162.000 jiwa yang tersebar di 5 kecamatan dan 22 kelurahan. Dengan jumlah penduduk tersebut maka diprediksi produksi sampahnya perhari sekitar $76.000 \mathrm{~kg}$. Dapat dibayangkan jika sampah sebanyak itu tidak mampu dikelola tentu akan menimbulkan banyak masalah terutama pencemaran terhadap lingkungan. ${ }^{2}$ Kota Metro juga dikenal sebagai Kota Pendidikan, karena memiliki ratusan jumlah sekolah dan 14 Perguruan Tinggi, sehingga mendorong banyaknya siswa dan mahasiswa yang berasal dari luar Kota Metro, baik dari Kabupaten/Kota yang ada di Provinsi Lampung maupun daerah dari luar Provinsi Lampung.

Hal tersebut selain memberikan dampak positif juga memberi dampak negatif bagi Kota Metro, termasuk salah satunya adalah peningkatan jumlah penduduk yang berpengaruh pada peningkatan volume sampah.Diperkirakan setiap orang menghasilkan sampah (langsung maupun tidak langsung) minimal sekitar $0,5 \mathrm{Kg}$ perharinya. Sampah-sampah yang berasal dari kawasan komersial (pasar dan pertokoan) dan permukiman di pusat-pusat kota dibuang di tempat pembuangan akhir (TPA) Karangrejo dengan luas 7,8 Ha yang pengolahannya masih menggunakan sistem open dump. TPA Karangrejo belakangan juga telah berusaha mengembangkan pengelolaan sampah di TPA menjadi biogas. Meski masih dalam tahap ujicoba dengan kapasitas yang terbatas hal ini tentunnya perlu diapresiasi. ${ }^{3}$

Selama ini kegiatan pengelolaan sampah di Kota Metro diatur dalam Peraturan Daerah Nomor 08 Tahun 2015 tentang Pengelolaan Sampah. Berdasarkan Peraturan Daerah Kota Metro Nomor 08 Tahun 2015 tentang Pengelolaan Sampah, dengann tujuan mewujudkan daerah yang bersih demi meningkatkan kesehatan masyarakat dan kualitas lingkungan serta menjadikan sampah sebagai sumber daya, sekaligus untuk mengantisipasi jumlah gunungan sampah di TPA Karangrejo Kecamatan Metro Utara.

Selama ini pola hidup masyarakat masih menganggap sampah sebagai sesuatu yang harus dibuang dan disingkirkan, serta pengelolaan sampah hanya dilakukan sebagai sesuatu yang bersifat rutin, yaitu hanya dengan cara membuang, memindahkan dan memusnahkan sampah.

2 http://ppsp.nawasis.info/dokumen/perencanaan/sanitasi/pokja/ssk/kota.metro/BAB $\% 202 \% 20 \mathrm{DRAFF} \% 20 \mathrm{SSK} \% 20$ KOTA\%20METRO.pdf diakses tanggal 8 Mei 2017

3 Berdasarkan Wawancara dengan Bapak Maksum Petugas di TPA Karang Rejo, 7 Juli 2017. 
Pada akhirnya hal ini berdampak pada semakin banyaknya produksi sampah dan semakin menggunungnya Tempat Pembuangan Akhir Sampah (TPAS) Karangrejo.

Mengantisipasi hal tersebut, diperlukan kepedulian masyarakat untuk berperanserta dan bersama-sama menyelasaikan persoalan sampah sebagai masalah bersama. Kegiatan membangun partisapasi masyarakat terkait erat dengan memberdayakan masyarakat serta mengembangkannya, karena di samping memerangi permasalahan sampah dan kebersihan lingkungan juga mendorong masyarakat menjadi lebih aktif dan penuh inisiatif. ${ }^{4}$

Kesadaran beberapa kelompok masyarakat dengan mendirikan beberapa Bank Sampah di Kota Metro adalah gerakan yang harus terus menerus digiatkan dalam rangka merubah kebiasaan mayoritas masyarakat yang selama ini masih menumpuk, membakar dan membuang sampah ke saluran irigasi, karena hal tersebut bisa berdampak serius pada kesehatan, polusi, dan banjir, termasuk berdampak buruk pada nilai estetika kota.

Beberapa Bank Sampah yang saat ini dijalankan oleh warga terdapat di Kelurahan Rejomulyo Kecamatan Metro Selatan adalah Bank Sampah CangKir Hijau I, Bank Sampah Wijaya Kusuma Kelurahan Tejoagung Kecamtanan Metro Timur, Bank Sampah CangKir Hijau II, Kelurahan Iring Mulyo Kecamatan Metro Timur, Bank Sampah Mandiri di Keluruhan Yosomulyo Kecamatan Metro Pusat, Bank Sampah Imopuro di Kelurahan Imuporo, dan Bank Sampah Hadimulyo Barat di Keluruahan Hadimulyo Barat Kecamatan Metro Pusat. ${ }^{5}$

Kehadiran beberapa Bank Sampah sebagai bentuk partisipsi warga tersebut sangat penting sekali untuk memutus mata rantai panjang sampah rumah tangga ke tempat pembuangan akhir. Meskipun yang berkembang selama ini adalah Bank Sampah konvensional yang mekanisme bank sampah sendiri sebetulnya tidak jauh berbeda dengan bank-bank pada umumnya, hanya saja yang menjadi komoditas di bank sampah ini adalah sampah itu sendiri dan bukan uang.

Dalam bank sampah terdapat mekanisme bagi hasil di mana keuntungan dari sampah yang dijual oleh bank sampah. Presentase bagi hasilnya pun bervariasi, ada yang dengan sistem tabungan, nasabah menabung dengan sampah dan dikonversi dengan nilai dan nominal tertentu sesuai harga pasar sampah yang ditabung, ada yang beli putus sebagaimana di tukang rongsokan. Dalam kasus seperti ini,Bank Sampah tentu saja mendapatkan presentase keuntungan yang lebih besar.Maka, agar lebih menarik penelitian ini menawarkan Pengembangan Bank Sampah Syariah dalam pengelolaan sampah, dengan mekanisme bagi hasil sesuai dengan Ekonomi Islam, karena dalam Ekonomi Islam terdapat akad kerjasama yang saling menguntungkan yang disebut mudhorobah, dimana nasabah sebagai shohibul maal dan bank sebagai mudhorib.

Mekanisme pembiayaan dalam Bank Sampah Syari'ah juga bisa berlandaskan atas asas Ekonomi Islam melalui akad al-Qordh, dimana bank sampah memberikan pinjaman tanpa meminta imbalan diawal dan nasabah juga diperbolehkan membayar hutangnya dengan sampah, jadi tidak harus dibayar dengan uang.

\section{Metode Penelitian}

Metode penelitian hukum adalah suatu pelajaran yang memberikan uraian mengenai penalaran, dalil-dalil, postulat-postulat yang menjadi latar belakang dari setiap langkah dalam proses yang lazim ditempuh dalam kegiatan penelitian hukum. Kemudian memberikan alternatif dan petunjuk-petunjuk dalam memilih alternatif tersebut serta membandingkan unsur-unsur penting dalam rangka yang dipakai dalam penelitian hukum.Menurut Soerjono Soekanto mengenai definisi penelitian hukum adalah sebagai kegiatan ilmiah yang didasarkan pada metode, sistematika dan pemikiran tertentu yang bertujuan untuk mempelajari sesuatu atau beberapa gejala hukum tertentu dengan jalan menganalisa untuk kemudian mengadakan sesuatu pemecahan atas permasalahan yang timbul pada gejala yang bersangkutan. ${ }^{6}$

4 Sunyoto Usman, Pembangunan dan Perbedayaan Masyarakat. Yogyakarta: Pustaka Pelajar Offset, 2006. Hal. 29.

5 Data mengenai Bank Sampah ini sesuai dengan Data yang ada di Kantor Lingkungan Hidup (KLH) Kota Metro sebagaimana penuturan Kepala KLH Kota Metro, Yerri Noer Kartiko, tanggal 20 Mei 2015 kepada pojoksamber.com.

6 Soerjono Soekanto. Pengantar Penelitian Hukum, Jakarta: Universitas Indonesia, 1981. Hal. 41 
Penelitian ini termasuk dalam penelitian kualitatif dengan menggunakan metode pendekatan sosio-legal, yang pada dasarnya berkaitan dengan perundang-undangan,yaitu tengangpartisipasi masyarkat lewat pengembangan Bank Sampah Syari'ah di Kota Metrosebagai upaya implementasi Perda Kota Metro No. 08 Tahun 2015 tentang Pengelolaan Sampah

Umumnya penelitian deskriptif ini tujuan utamanya adalah menggambarkan secara sistematis fakta dan karakteristik objek atau subjek yang diteliti secara tepat, dan memberikan data yang seteliti mungkin tentang manusia, keadaan, atau gejala-gejala lain. Maksud utamanya adalah untuk mempertegas hipotesa-hipotesa, agar dapat membantu didalam memperkuat teoriteori lama, atau didalam kerangka menyusun teori-teori baru. ${ }^{7}$

Burhan Ashshofa dalam bukunya Metode Penelitian Hukum menjelaskan bahwa pendekatan kualitatif diartikan sebagai pendekatan yang memusatkan perhatiannya pada prinsip-prinsip umum yang mendasari perwujudan satuan-satuan gejala yang ada dalam kehidupan manusia, atau pola-pola yang dianalisis berupa gejala-gejala sosial budaya dengan menggunakan kebudayaan dari masyarakat yang bersangkutan untuk memperoleh gambaran mengenai polapola yang berlaku, seperti melalui pedoman wawancara, dokumentasi, dan studi pustaka.

\section{Fokus Penelitian}

Di dalam penelitian kualitatif menghendaki ditetapkannya batas atas dasar masalah penelitian. Masalah dalam penelitian kualitatif dinamakan fokus, ${ }^{8}$ pemikiran fokus meliputi perumusan latar belakang, studi dan permasalahan, ini berarti fokus adalah penentuan keluasan permasalahan dan batas penelitian. Penetapan fokus penelitian merupakan tahap yang sangat menentukan dalam penelitian kualitatif.

Hal tersebut karena penelitian kualitatif tidak dimulai dari yang kosong atau adanya masalah, baik masalah yang bersumber dari pengalaman peneliti atau melalui pengamatan pengetahuannya yang di peroleh melalui kepustakaan ilmiah. Jadi fokus dalam penelitian kualitatif bersifat tentatif, artinya penyempurnaan rumusan fokus atau masalah itu masih tetap dilakukan sewaktu peneliti sudah berada di latar penelitian.

Dan yang menjadi fokus penelitian ini adalah mengenai apa saja bentuk-bentuk regulasi terkait dengan pengelolaan sampah di Kota Metro, apaah kendala dan bagaimanakah mekanisme partisipasi masyarakat lewat pengembangan Bank Sampah Syari' ah sebagai upaya implementasi Perda Kota Metro No. 08 tahun 2015 tentang Pengelolaan Sampah di Kota Metro.

\section{Sumber Data}

\section{a. Data Primer}

Data primer merupakan data hasil dari wawancara maupun data tertulis yang merupakan hasil penelitian di lapangan yang dilakukan secara terstruktur. Dalam wawancara terstruktur terlebih dahulu dipersiapkan instrumen yang berupa daftar pertanyaan yang berfungsi sebagai pedoman pada saat wawancara berlangsung, wawancara tersebut meliputi: (1) Bentuk-bentuk regulasi terkait dengan pengelolaan sampah di Kota Metro (2) Bentuk dan mekanisme partisipasi masyarakat dalam pengelolaan sampah di Kota Metro (3) Kendala partisipasi masyarakat dalam penanganan Sampah di Kota Metro, (4) Konsep pengembangan Bank Sampah Syariah dengan sistem Muzara'ah dalam rangka pengelolaan sampah di Kota Metro.

Dalam melakukan wawancara yang dilakukan oleh pewawancara adalah mencari informasi, informasi tersebut melalui, (1) Responden; responden adalah orang yang ditentukan sebagai sampel dalam penelitian ini dan diharapkan dapat menjawab pertanyaan yang diajukan oleh peneliti. Responden dalm penelitian ini yaitu: UPT Kebersihan Kota Metro, Kantor Lingkungan Hidup Kota Metro, kelompok Pengelola Bank Sampah di Kota

8 Lexy J. Moleong, Metodologi Penelitian Kualitatif, Bandung: Penerbit PT Remaja Rosdakarya. Offset, 2007. Hal.62 
Metro, Wakil Masyarakat dan Akademisi, serta pihak-pihak yang terkait langsung dalam pengelolaan sampah di Kota Metro. (2) Informan; informan adalah orang yang dimanfaatkan untuk memberikan informasi tentang dan kondisi latar penelitian ${ }^{9}$ Informan yang dimaksud dalam penelitian ini adalah pihak-pihak lain di luar responden, jika dibutuhkan.

\section{b. Data Sekunder}

Data sekunder merupakan data yang berhubungan erat dengan data primer sehingga dapat membantu menganalisis dan memahami data primer. Data sekunder yang diperlukan dalam penelitian ini didapatkan dari dokumen-dokumen mengenai partisipasi masyarakat dalam pengelolaan Sampah di Kota Metro.

\section{Alat dan Teknik Pengumpulan Data}

Dalam penelitian ini yang dimaksud data adalah segala sesuatu yang hanya berhubungan dengan keterangan tentang pengelolaan sampah di Kota Metro. Penulis menggunakan metode pengumpulan data-data primer dan data-data sekunder yang akan diuraikan sebagai berikut:

\section{a. Wawancara}

Wawancara adalah percakapan dengan maksud tertentu. Percakapan itu dilakukan oleh dua pihak yaitu pewawancara yang mengajukan pertanyaan dan yang diwawancarai yang memberikan jawaban atas pertanyaan itu. ${ }^{10}$

Wawancara merupakan salah satu alat pengumpulan data dengan mengajukan pertanyaan secara lisan untuk dijawab secara lisan pula. Dalam hal ini wawancara dilakukan untuk memperoleh informasi dan untuk mengungkapkan data tentang : (1) Bentuk regulasi terkait pengelolaan sampah di Kota Metro (2) Bentuk dan mekanisme pengelolaan sampah di Kota Metro. (3) Kendala partisipasi masyarakat dalam penanganan Sampah di Kota Metro, dan (4) Peluang Pengembangan Bank Sampah Syari'ah dalam pengelolaan sampah di Kota Metro.

Informasi tersebut didapatkan dari wawancara yang dilakukan dengan berpedoman pada pertanyaan-pertanyaan terbuka yang disusun sebagai instrumen untuk mendapatkan data penelitian.

\section{b. Dokumentasi}

Dokumentasi adalah metode yang digunakan dengan cara mencari data mengenai halhal yang berupa catatan dokumentasi. Selain menggunakan metode wawancara penelitian ini juga menggunakan metode dokumentasi guna melengkapi data yang sebelumnya agar mendapatkan sebuah data yang lengkap dan objektif. Dalam penelitian metode dokumentasi yang digunakan untuk memperoleh data adalah : (1) Peraturan Perundang-Undangan yang berkaitan dengan Pengelolaan sampah di Kota Metro, (2) Peraturan Daerah yang berkaitan dengan Pengelolaan sampah di Kota Metro, dan (3) Dokumen Pengelolaan Sampah di Kota Metro.

\section{Keabsahan Data}

Teknik pemeriksaan keabsahan informasi atau data dalam penelitian ini menggunakan tehnik check dan recheck atau bisa disebut dengan teknik triangulasi diantaranya yaitu dengan cara membandingkan data hasil studi pustaka dengan data hasil wawancara dengan narasumber.

Dalam penelitian ini, peneliti menggunakan teknik triangulasi yaitu teknik pemeriksaan keabsahan data yang memanfaatkan suatu yang lain diluar data itu untuk keperluan pengecekan atau sebagai pembanding terhadap data itu. Teknik yang digunakan peneliti adalah pemeriksaan

$9 \quad$ Ibid. Hal. 132

10 Ibid. Hal. 186 
melalui sumber lainnya yang dapat dicapai dengan jalan membandingkan data hasil wawancara dengan hasil studi pustaka.

\section{Teknik Analisis Data}

Sebagai cara untuk menguraikan dari hasil penelitian yang sudah terkumpulkan, akan digunakan metode analisis kualitatif. Kualitatif dimaksudkan data yang diperoleh dijabarkan dalam uraian yang tersusun secara sistematis dan dilaksanakan dengan mendasarkan pada argumentasi linguistik nonstsatistik.

Data analisis kualitatif yang sudah tekumpul dari studi kepustakaan akan dianalisa dan dikaji kemudian disistematikakan menjadi analisis yang disusun dalam bentuk laporan penelitian. Secara singkat desain penelitian ini dapat dalam skema sebagai berikut :

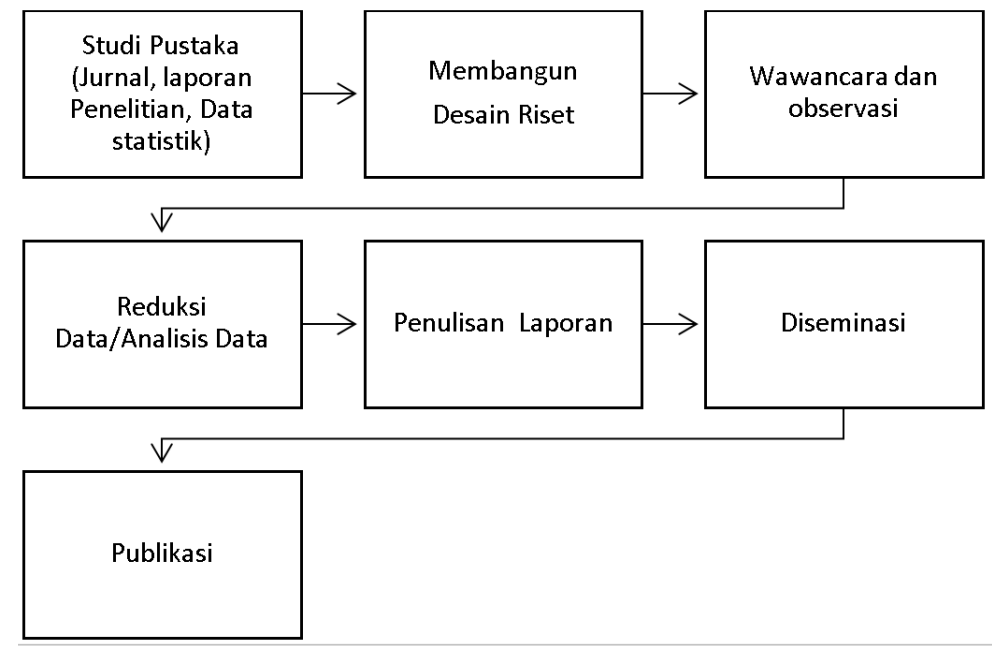

Gambar. 1 Alur Analisis Data

\section{Hasil dan Pembahasan}

\section{Pengembangan Bank Sampah di Kota Metro}

Payung hukum dalam pengembangan Bank Sampah di Kota Metro ialah UndangUndang Nomor 18 tahun 2008 tentang Pengelolaan Sampah. Beserta Peraturan Pemerintah Nomor 81 Tahun 2012 yang mengamanatkan perlunya perubahan paradigma yang mendasar dalam pengelolaan sampah yaitu dari paradigma kumpul-angkut-buang menjadi pengolahan yang bertumpu pada pengurangan sampah dan penanganan sampah. Kegiatan pengurangan sampah bermakna agar seluruh lapisan masyarakat, baik pemerintah, dunia usaha maupun masyarakat luas dalam melaksanakan kegiatan pembatasan timbulan sampah, pendauran ulang dan pemanfaatan kembali sampah atau yang lebih dikenal dengan sebutan Reduce, Reuse dan Recycle (3R) melalui upayaupaya cerdas, efisien dan terprogram.

Melalui program Bank Sampah di Kota Metro ini, merupakan kegiatan social engineering yang mengajarkan masyarakat untuk memilah sampah serta menumbuhkan kesadaran masyarakat dalam pengolahan sampah secara bijak dan pada akhirnya akan mengurangi sampah yang diangkut ke Tempat Pembuangan Akhir Sampah (TPAS) Karang Rejo.

Ada banyak Bank Sampah di Kota Metro yang saat ini dijalankan oleh warga terdapat di Kelurahan Rejomulyo Kecamatan Metro Selatan adalah Bank Sampah CangKir Hijau I, Bank Sampah Wijaya Kusuma Kelurahan Tejoagung Kecamtanan Metro Timur, Bank Sampah CangKir Hijau II, Kelurahan Iring Mulyo Kecamatan Metro Timur, Bank Sampah Mandiri di Keluruhan Yosomulyo Kecamatan Metro Pusat, Bank Sampah Imopuro di Kelurahan Imuporo, dan Bank Sampah Hadimulyo Barat di Keluruahan Hadimulyo Barat Kecamatan Metro Pusat. ${ }^{11}$

11 Data mengenai Bank Sampah ini sesuai dengan Data yang ada di Kantor Lingkungan Hidup (KLH) Kota Metro sebagaimana penuturan Kepala KLH Kota Metro, Yerri Noer Kartiko, tanggal 20 Mei 2015 kepada pojoksamber.com. 
Penelitian ini mengambil sample Bank Sampah yang ada di Kelurahan Iring Mulyo Kecamatan Metro Timur dan Kelurahan Rejomulyo Kecamatan Metro Selatan, yakni Bank Sampah Cangkir yang pendiriannya diinisiasi sendiri oleh masyarakat yang tergabung dalam Komunitas Cangkir Kamisan Kota Metro, sehingga partisipasinya lebih murni berawal dan dikembangkan oleh warga. Bank Sampah ini dikelola oleh beberapa anak muda diantaranya, Erik Pujianto, Lukman Hakim, Rinaldi, Arif Budi Siswanto, Abdurrahman Wahid, Elman dan Elfan, dan dibina oleh beberapa pembina dari beberapa kampus yang ada di Kota Metro, termasuk Dr. Bambang Suhada dari Unversitas Muhammadiyah Metro. ${ }^{12}$

Bank Sampah Cangkir Hijau ini didedikasikan sebagai wadah untuk membina masyarakat dalam kegiatan pengolahan sampah dari hulu ke hilir Kota Metro dalam rangka pengurangan sampah TPAS dan pemberdayaan ekonomi masyarakat dengan memanfaatkan sampah. Pengembangan yang dilakukan sedikit demi sedikit mengubah cara pandang dan perilaku masyarakat Kota Metro dalam mengelola sampah.

Sampai bulan Agustus 2016, sudah ada 13 unit Bank Sampah di bawah pembinaan Kantor Lingkungan Hidup Kota Metro, dan sekitar 20 Bank Sampah yang dikelola oleh masyarakat dan sekolah, di samping adanya instalasi-instalasi pencacahan sampah plastik.

Sedangkan sampah yang terambil perhari mencapai $25 \%$ dari total sampah yang dihasilkan warga yang berjumlah sekitar 170 ton. Sampah-sampah yang dikumpulkan di bank sampah tersebut oleh masyarakat dibuat kerajinan, sebagian dipress, sebagian lagi diolah ulang menjadi biji plastik kemudian dijual ke industri. Selain menggalakkan bank sampah, Pemkot Metro juga memiliki dua unit instalasi yang mengolah sampah organik menjadi biogas dengan kapasitas 7 meter kubik. Energi listrik yang dihasilkan dari instalasi tersebut dimanfaatkan untuk 15 hingga 20 rumah. ${ }^{13}$

Untuk sosialisasi yang dilakukan oleh Bank Sampah Cangkir Hijau Kota Metro yang mendapat dukungan dari pemerintah Kota Metro dan CSR dari Rumah Sakit AMC Metro berupa sepeda motor bak untuk terselenggaranya pengelolaan sampah dalam rangka mengurangi timbunan sampah di TPA di Karang Rejo, dan penerapan prinsip 3R sedekat mungkin dengan sumber sampah dan juga diharapkan dapat menyelesaikan masalah sampah secara terintegrasi dan menyeluruh sehinga tujuan akhir kebijakan Pengelolaan Sampah dapat dilaksanakan dengan baik sesuai Perda Kota Metro No. 8 Tahun 2015 tentang Pengelolaan Sampah

\section{Bentuk Partisipasi Masyarakat}

Kota Metro tentunya ingin melihat daerahnya bersih, rapi, dan sehat. Oleh karena itu, bentuk partisipasi masyarakat tidak hanya sampai pada penanganan dan pengurangan sampah, tetapi lebih sebagai pengawas di lingkungannya untuk menjaga lingkungannnya senantiasa bebas dari sampah. Bentuk partisipasi masyarakat dalam pengelolaan sampah yang dilakukan oleh masyarakat Kota Metro adalah dalam bentuk memilah sampah yang dilakukan oleh masyarakat sendiri dan di setorkan ke Bank Sampah untuk ditabung. Hal ini merupakan bentuk dari partisipasi masyarakat guna membantu pengembangan Bank Sampah serta dapat mempertahankan kesadaran masyarakat akan pentingnya mengelola sampah. Bentuk lain dari partisipasi masyarakat adalah dengan melakukan daur ulang sampah organik menjadi pupuk kompos. pupuk hasil olahan sebagian dijual dan sebagian lagi untuk pupuk tanaman warga. Selain itu ada juga pembuatan biopori yang berfungsi untuk resapan air, hal ini berguna untuk mempercapat meresapnya air ke dalam tanah sehingga dapat terhindar dari banjir.

Partisipasi yang diberikan masyarakat berupa kewajiban melakukan pemilahan sampah rumah tangga berupa organik maupun anorganik yang dilaksanakan oleh masyarakat sendiri kemudian diserahkan ke Bank Sampah. Hal ini seperti yang diamanatkan dalam Peraturan Menteri Lingkunan Hidup No. 13 Tahun 2012 Tentang Pedoman Pelaksanaan Reduce, Reuse dan Recycle (3R) melalui Bank Sampah.

12 Wawancara dengan Erik Pujianto Pengurus Bank Sampah Cangkir Hijau II Iring Mulyo Kota Metro, tanggal 10 Juli 2017

13 Wawancara dengan Rinaldi, Pengelola Bank Sampah Cangkir Hijau I Rejomulto Metro Selatan tanggal 22 Juli 2017 
Faktor pendukung dalam pengembangan Bank Sampah di Kota Metro tidak lepas dari beberapa peranan dari Pemerintah. Pemerintah Kota Metro, memiliki tanggungjawab dalam penyediaan prasarana dan sarana dalam pengelolaan sampah, sedangkan faktor penghambat hanyalah persoalan menjaga semangat masyarakat untuk terus memilah sampah agar tidak turun karena nilai sampah yang rendah merupakan faktor paling utama dalam program bank sampah ini. Sehingga terus memerlukan pendampingan dalam memilah sampah, dengan memperbanyak program-program seperti sosialisasi, pelatihan/pembinaan, operasional pengelolaan sampah dll, dalam hal ini sangat membutuhkan dukungan anggaran baik dari pemerintah maupun swasta.

Pengembangan Bank Sampah menjadi Bank Sampah Syari'ah, khususnya Bank Sampah Cangkir Hijau sangat mungkin dilakukan sebagai pendekatan peningkatan partisipasi masyarakat Kota Metro yang memang cenderung relegius dengan penganut Islam mayoritas. Ajaran-ajaran agama untuk menjaga kelestarian lingkungan dan kebersihan akan mendorong partisipasi warga dalam rangka implementasi Perda No. 8 Tahun 2015 tentang Pengelolaan Sampah. Dan, model yang lebih dekat untuk diterapkan pada praktik Bank Sampah Syari'ah, khususnya dalam penelitian ini adalah konsep muzara'ah. Yakni Bank Sampah Syari'ah memberi hasil penjualan sampah dan tidak boleh seseorang memberi hasil penjualan sampah pada pengurus Bank sampah kecuali dengan pemberian yang sudah dapat diketahui oleh kedua belah pihak, baik penabung maupun pelaksana/pengurus Bank sampah.

\section{Simpulan dan Saran}

\section{Simpulan}

Pengembangan Bank Sampah di Kota Metro dilaksanakan sesuai dengan UU No. 18 Tahun 2008 tentang Pengelolaan Sampah, Peraturan Pemerintah Nomor 81 tahun 2012 tentang Pengelolaan Sampah Rumah Tangga dan Sampah Sejenis Sampah Rumah Tangga, Peraturan Menteri Negara Lingkungan Hidup Republik Indonesia Nomor 13 Tahun 2012 Tentang Pedoman Pelaksanaan Reduce, Reuse, dan Recycle Melalui Bank Sampah, dan Perda Kota Metro No. 8 Tahun 2015 tentang Pengelolaan Sampah merupakan kekuatan hukum yang merubah cara pandang tentang pengelolaan sampah dan keberadaan bank sampah.

Dalam pengembangan Bank Sampah Metro Syari'ah sangat membutuhkan pastisipasi dari masyarakat agar program pengolahan sampah dapat berjalan berdasarkan prinsip 3R. Seperti yang diamanatkan dalam Peraturan Menteri Lingkunan Hidup No. 13 Tahun 2012 Tentang Pedoman Pelaksanaan Reduce, Reuse dan Recycle (3R) Melalui Bank Sampah. Partisipasi yang diberikan masyarakat berupa kewajiban melakukan pemilahan sampah rumah tangga berupa organik maupun anorganik yang dilaksanakan oleh masyarakat sendiri.

Dalam pelaksanaan program Bank Sampah di Kota Metro ini tidak terlepas dari beberapa faktor pendukung dan faktor penghambat. Faktor pendukung dalam pengembangan Bank Sampah adalah peran Pemerintah Daerah sebagai Pendukung pelaksanaan Program Bank Sampah serta kesadaran sebagian Masyarakat Kota Metro sudah terbentuk kerena pada dasarnya kegiatan pengelolaan sampah melalui Bank Sampah memberikan berbegai dampak positif berbagai aspek, seperti yang di sebutkan pada poin pertama. Sedangkan untuk faktor penghambat ada beberapa poin antara lain adalah: (a) kesadaran sebagian masyarakat yang masih rendah, (b) banyaknya kegiatan Bank Sampah yang membutuhkan anggaran, sehingga membutuhkan anggaran tetap setiap tahun dari berbagai pihak (pemerintah maupun swasta), (c) nilai sampah yang rendah, (d) persaingan dengan para pengumpul sampah (bos rongsokan) yang memiliki modal lebih besar.

\section{Saran}

a. Komunikasi formal antara Bank Sampah, perlu adanya dukungan berkelanjutan dari Pemerintah Kota Metro dalam pengembangan Bank Sampah di Kota Metro terkait upaya pengurangan timbunan sampah di TPA Karang Rejo Metro Utara, sehingga 
pengolahan sampah di Bank Sampah tetap terjaga dan mencapai tujuan bersama.

b. Peningkatan sosialisasi tidak hanya terkait dengan pengelolaan anorganik melainkan pengelolaan sampah organik dengan berbagai metode yaitu composer dan penyedian alat pengolahan sampah yang bisa menjadi pusat pengelolaan sampah organik.

c. Mengoptimalkan anggaran dari Pemerintah Kota Metro dalam pengembangan Bank Sampah, Hal ini karena banyak kegiatan Bank Sampah di Kota Metro yang membutuhkan dana.

\section{Daftar Pustaka}

Burhan Ashshofa, Metode Penelitian Hukum, Jakarta: Rineka Cipta, 1996

Ismaya Sujana, Kamus Perbankkan, Bandung: Pustaka Grafika, 2006

Lexy J. Moleong, Metodologi Penelitian Kualitatif, Bandung: Penerbit PT Remaja Rosdakarya. Offset, 2007

Soerjono Soekanto. Pengantar Penelitian Hukum, Jakarta: Universitas Indonesia, 1981

Sondang P. Siagian, Administrasi Pembangunan: Konsep, Dimensi, dan Strateginya. Jakarta, Bumi Aksara, 2003

Sunyoto Usman, Pembangunan dan Perbedayaan Masyarakat. Yogyakarta: Pustaka Pelajar Offset, 2006

Suwerda Bambang, Bank Sampah Kajian Teori dan Penerapan, Yogyakarta: Pustaka Rihama, 2012

Syafi'i antonio, Muhammad, Bank Syari'ah Dari Teori Ke Praktik, Jakarta: Gema Insani Pres, 2001

Y. Slamet, Pembangunan Masyarakat Berwawasan Partisipasi. Surakarta: Sebelas Maret University Press, 1994

http://ppsp.nawasis.info/dokumen/perencanaan/sanitasi/pokja/ssk/kota.metro/BAB $\% 202 \% 20$ DRAFF\%20SSK\%20KOTA\%20METRO.pdf

\section{Peraturan Perundang-Undangan}

Undang Undang Nomor 18 Tahun 2008 tentang Pengelolaan Sampah

Peraturan Pemerintah Nomor 81 Tahun 2012 tentang Pengelolaan Pampah

Perda Kota Metro No. 8 Tahun 2015 Tentang Pengelolaan Sampah 